\title{
Fusarium Head Blight and Deoxynivalenol Accumulation of Barley in Eastern Canada: Cultivar Response and Correlation Analysis
}

T. M. Choo, Eastern Cereal and Oilseed Research Centre, Agriculture and Agri-Food Canada, Ottawa, Ontario, Canada K1A 0C6; R. A. Martin, Crops and Livestock Research Centre, Agriculture and Agri-Food Canada, Charlottetown, PEI, Canada C1A 4N6; K. M. Ho, Eastern Cereal and Oilseed Research Centre, Agriculture and Agri-Food Canada, Ottawa, Ontario, Canada K1A 0C6; Q. Shen, Zhejiang Academy of Agricultural Sciences, 48 Shiqiao Road, Hangzhou, China 310021; G. Fedak, M. Savard, and H. Voldeng, Eastern Cereal and Oilseed Research Centre, Agriculture and Agri-Food Canada, Ottawa, Ontario, Canada K1A 0C6; D. E. Falk, Department of Plant Agriculture, University of Guelph, Guelph, Ontario, Canada N1G 2W1; M. Etienne, W. G. Thompson and Sons Ltd., Nairn Research Lab., R. R. \#1, Ailsa Craig, Ontario, Canada N0M 1A0; and E. Sparry, C \& M Seeds, R. R. \#3, Palmerston, Ontario, Canada NOG 2P0

\begin{abstract}
Choo, T. M., Martin, R. A., Ho, K. M., Shen, Q., Fedak, G., Savard, M., Voldeng, H., Falk, D. E., Etienne, M., and Sparry, E. 2004. Fusarium head blight and deoxynivalenol accumulation of barley in eastern Canada: Cultivar response and correlation analysis. Plant Dis. 88:837-844.

Fusarium head blight of barley (Hordeum vulgare) is a devastating disease in many countries. We undertook a study to identify barley cultivars, if any, that are resistant to Fusarium head blight and deoxynivalenol (DON) accumulation and to determine if DON concentration is correlated with other plant traits in Eastern Canada and China. Barley cultivars were grown in the field under artificial inoculation conditions at two locations (Charlottetown and Ottawa) in Canada during two summers and at Hangzhou in China during two winters. Seed samples were collected for DON analysis from the barley performance trial at five locations in Ontario. None of the 64 barley cultivars were immune to Fusarium head blight infection. Two-row cultivars, however, were significantly more resistant to Fusarium head blight infection and DON accumulation than six-row cultivars. Three cultivars (Island, AC Alberte, and Chevron) were found to be most resistant, as they were consistently low in Fusarium head blight incidence and DON concentration in both Eastern Canada and China. In six-row barley, DON concentration was correlated positively with Fusarium head blight incidence at both Charlottetown and Ottawa, and it was negatively correlated with plant height at Ottawa. DON concentration and heading date were not consistently correlated. Barley yellow dwarf and powdery mildew appeared to have very little effect on Fusarium head blight infection. Susceptibility to DON accumulation did not result in low yield under natural infection conditions in Ontario. Cultivar $\times$ location interactions for DON concentration, Fusarium head blight incidence, and heading date were significant.
\end{abstract}

Additional keywords: scab, vomitoxin

Fusarium head blight of barley (caused by Fusarium spp.) is a devastating disease in many parts of the world, including North America $(2,18,31)$, Europe (1), and the Far East $(12,13,15)$. Fusarium head blight gives rise to accumulation of deoxynivalenol (DON) in the grains. Therefore, measures to control Fusarium head blight are needed to reduce DON contamination in grain that is destined for feed or food. Identification of Fusarium head blight-resistant cultivars and a better understanding of the interrelationships be-

Corresponding author: T. M. Choo

E-mail: ChooTM@agr.gc.ca

Accepted for publication 24 March 2004.

Publication no. D-2004-0604-01R

This article is in the public domain and not copyrightable. It may be freely reprinted with customary crediting of the source. The American Phytopathological Society, 2004. tween DON accumulation and other plant traits should be of value in developing control measures for Fusarium head blight.

In Eastern Canada (i.e., east of the Manitoba-Ontario border), barley is as susceptible to DON accumulation as wheat (3). Recently, Tekauz et al. (31) found that the barley cultivar AC Sterling, which was developed in Eastern Canada, contained only a low level of DON (1.2 mg kg-1) after being sprayed with a Fusarium graminearum suspension. We believe that, in addition to AC Sterling, other barley cultivars from Eastern Canada could also have a good level of resistance to Fusarium head blight.

A number of plant traits could facilitate Fusarium head blight infection, which in turn could lead to reduction of seed weight, test weight, and grain yield. Barley plants under biotic or abiotic stresses could have a weakened defense system. In wheat, for example, Fusarium head blight is less severe for those cultivars with low levels of powdery mildew (caused by Blumeria graminis) (20), and it is less severe where glume blotch (caused by Stagonospora nodorum) is controlled by fungicide (17). In many environments, seeds of taller cultivars contain less DON than those of shorter cultivars $(8,16,34)$. The correlation between heading date and DON concentration has been reported as positive (34), negative $(8,34)$, or nonsignificant (16). Two-row barley is more resistant to Fusarium head blight than six-row barley $(28,29,33)$. Under artificial inoculation conditions, infected heads produce fewer seeds, lower seed weight, and lower seed yield per spike in barley $(4,22)$.

Quantitation of DON concentration is a time-consuming and labor-intensive process. It involves harvesting, de-awning, grinding, and chemical testing of seed samples. If the visual symptom of Fusarium head blight is correlated with DON concentration, then one can use the visual ratings to predict the severity of DON contamination and to carry out indirect selection for resistance to DON accumulation without resorting to chemical testing. Information on correlation between visual ratings of Fusarium head blight and DON concentration is limited in barley. Visual ratings of Fusarium head blight are sometimes complicated by the presence of spot blotch (caused by Bipolaris sorokiniana). In mapping populations, DON concentration has been found in many cases to be positively correlated with Fusarium head blight severity $(8,16,32,34)$. DON concentration, however, was not correlated with Fusarium head blight severity when a mapping population was grown in Hangzhou in 1997 (8). A positive, but weak correlation between DON concentration and Fusarium head blight severity $(r=$ 0.31 to 0.56 ) has been reported in barley seed samples harvested from commercial fields in Minnesota, North Dakota, and South Dakota (23). On the other hand, the DON concentration and Fusarium head blight index of 16 barley cultivars were not correlated when grown in Manitoba (31). More research is warranted in barley to 
determine the level of correlation, if any, between Fusarium head blight ratings and DON concentration.

Several workers in North America have been using locations in China as an offseason nursery for screening for Fusarium head blight resistance $(8,16,27,34)$. The usefulness of the off-season nursery in China depends upon whether or not the response of barley lines to Fusarium head blight infection there is similar to that in North America. In one mapping study on barley, Fusarium head blight severity at Shanghai was correlated with DON concentration at North Dakota nurseries (34), but in another mapping study, DON concentration at Hangzhou was not correlated with that at two locations in the United States (8). No studies have been carried out to determine if the response of barley lines to Fusarium head blight in China is similar to that in Eastern Canada.

The objectives of this study were (i) to identify barley cultivars, if any, that are resistant to Fusarium head blight and DON accumulation and (ii) to determine if DON concentration is correlated with other plant traits in Eastern Canada and China. To our knowledge, this is the first extensive report on the response of local barley cultivars to Fusarium head blight and DON accumulation in Eastern Canada.

\section{MATERIALS AND METHODS}

Artificial inoculation tests. Artificial inoculation tests were conducted at Ottawa (Ontario) and Charlottetown (Prince Edward Island) in two summers (2000 and 2002) and at Hangzhou (Zhejiang Province, China) in two winters (2000-2001 and 2002-2003). Thirty-seven barley cultivars, 10 advanced breeding lines developed at the Eastern Cereal and Oilseed Research Centre, and the resistant check Chevron (24) were planted in a randomized complete block design with four replicates each at Ottawa and Charlottetown, and two replicates at Hangzhou. Seventeen cultivars were two-row types, and the remaining 31 were six-row types. These 37 cultivars were representative samples from the current barley cultivars available for production in Eastern Canada.

At Ottawa, the experimental material was seeded on 31 May 2000 and 9 (or 13) May 2002 at a seeding rate of $5 \mathrm{~g}$ per row. Each experimental plot consisted of two $1.5-\mathrm{m}$ rows with a row spacing of $15 \mathrm{~cm}$. The $F$. graminearum isolate DAOM 178148 from the National Mycological Herbarium (21) was used as inoculum. Equal parts by volume of corn and barley grains were mixed and soaked in water for $48 \mathrm{~h}$. Excess water was removed, and the kernel mixture was placed in an aluminum pan $(53 \times 32 \times 8 \mathrm{~cm})$ covered with two layers of aluminum foil and autoclaved for $1 \mathrm{~h}$ at $120^{\circ} \mathrm{C}$. In each pan, $100 \mathrm{ml}$ of spore suspension at a concentration of $5.5 \times 10^{4}$ spores per ml was evenly poured over the surface of the kernel mixture under a laminar flow hood. The kernel mixture was incubated at room temperature for at least 4 weeks. Infected kernels were broadcast at a rate of $30 \mathrm{~g} \mathrm{~m}^{-2}$ four times (28 June and 13, 20, and 27 July) in 2000, and twice (13 and 20 June) in 2002. The plots were watered with a sprinkler system twice a day (at 11:00 to 11:30 A.M. and 3:00 to 4:00 P.M.) for 20 to $30 \mathrm{~min}$ from the time of the first inoculation to a hard dough stage to increase humidity.

In 2000, yellow dwarf, caused by Barley yellow dwarf virus (BYDV), was severe at the seedling stages, and on 19 July, plots of each replicate were rated for yellow dwarf on a scale of 0 to 9 with 0 being no leaf chlorosis and 9 being severe leaf chlorosis. Heading date, plant height, and Fusarium head blight incidence (i.e., percentage of heads infected per row) were recorded in each replicate.

At maturity, all of the heads from the two-row plots were harvested and threshed. Approximately 20 to $25 \mathrm{~g}$ of seed was ground to pass through a $0.4 \mathrm{~mm}$ screen on a Udy-mill. One gram of flour was taken from the thoroughly mixed ground sample. To prepare extracts, $5 \mathrm{ml}$ of methanol:water $(1: 9, \mathrm{vol} / \mathrm{vol})$ were added to 1-g samples in 10-ml plastic tubes, which were subjected to end-overend mixing for $1 \mathrm{~h}$, then centrifuged for 5 $\mathrm{min}$ at 2,000 rpm. DON analysis was conducted on the filtrate following the enzyme-linked immunosorbent assay (ELISA) procedures described by Sinha et al. (26). The accuracy of the ELISA procedures has been reported to be comparable to that of the gas chromatography method (25). The limit of quantitation was $0.1 \mathrm{mg} \mathrm{kg}^{-1}$. Any sample with less than $0.1 \mathrm{mg} \mathrm{kg}^{-1}$ of DON was considered as having a zero concentration of DON.

At Charlottetown, the experimental material was seeded on 1 June 2000 and 24 May 2002 at a seeding rate of $3 \mathrm{~g}$ per row with a row spacing of $20 \mathrm{~cm}$. Each experimental plot consisted of one $0.5-\mathrm{m}$ row. The plots were sprayed with a conidial suspension of five $F$. graminearum isolates $\left(5.0 \times 10^{4}\right.$ spores per $\left.\mathrm{ml}\right)$ at a rate of 125 liters ha- ${ }^{-1}$. The five isolates were collected from barley and wheat plants in Prince Edward Island. The inoculum was applied three times (at heading, 7 days after heading, and 14 days after heading). The plots were watered with a misting system for 2 min every 30 min from heading to a hard dough stage. Plant height and Fusarium head blight incidence (i.e., percentage of heads infected per plot) were recorded in each plot in 2000, and heading date was recorded in 2002. DON concentration was determined for each plot in both years following the procedures described earlier.

At Hangzhou, the experimental material was seeded on 4 November 2000 and 13 November 2002 at a seeding rate of $5 \mathrm{~g}$ per row. Each plot consisted of one 0.2-m row with a row spacing of $33 \mathrm{~cm}$. Infected wheat kernels were broadcast at a rate of $7.5 \mathrm{~g} \mathrm{~m}^{-2}$ at the booting stage. At heading, each cultivar was also sprayed with an $F$. graminearum suspension $\left(5.0 \times 10^{4}\right.$ spores per $\mathrm{ml}$ ) at a rate of 150 liters $\mathrm{ha}^{-1}$ in the first-year test, or inoculated again with infected wheat kernels in the second-year test. A mixture of $F$. graminearum isolates collected from the cultivar Giu Damai from Hailing, Zhejiang, was used for the inoculation. The plots were watered twice a day with a sprinkler system for approximately $30 \mathrm{~min}$. Plant height, heading date, and Fusarium head blight incidence were recorded for each plot. Fusarium head blight incidence was rated on 30 heads.

Natural infection tests. The Ontario Cereal Crops Committee has been coordinating performance trials to generate field data that are useful for Ontario producers. The Ontario Barley Performance Trial was established at two locations in eastern Ontario (Ottawa and Westmeath) and three locations in western Ontario (Elora, Palmerston, and Winthrop) in 2000. Standard cultural practices were followed at each location. Either 40 or 41 barley entries were tested at each location, 37 of which were common to all five locations. Seventeen of these were not included in the artificial inoculation tests. Grain yield was determined in all plots. Test weight, seed weight, plant height, heading date, maturity date, and lodging resistance were recorded only in one replicate at each location. Seed samples for DON analysis were taken from the bulk of all four replicates at Westmeath and Palmerston and from one replicate at the other locations. The DON concentration was determined following the procedures described earlier. Note that Fusarium head blight of barley was epidemic in Ontario in 2000 (9).

Statistical analysis. The original data for Fusarium head blight incidence and DON concentration were first transformed into logarithms to stabilize the variance, and the transformed data were used to perform the analysis of variance. In the individual analysis of variance table, the (two-row versus six-row) mean square was compared with the within-types mean square with an $F$ test to determine if the two types of barley were different in Fusarium head blight incidence and DON accumulation. In the combined analysis over environments (i.e., year-location combinations), the cultivars mean square was compared with the cultivar $\times$ environment mean square by an $F$ test if the latter was significantly greater than the error (b) mean square. Means of cultivars were compared with the least significant difference test (LSD) at the 0.05 level. Pearson correlation coefficients between traits and between environments were calculated using cultivar means for both two-row and six-row types. A significant correlation 
coefficient between environments would indicate a small cultivar $\times$ environment interaction (10).

\section{RESULTS}

Artificial inoculation tests. The individual analysis of variance showed that, not only did the two-row type have less Fusarium head blight incidence than the six-row type in all five tests (Table 1), the two-row type also contained less DON in three of the four tests (Table 2). In the combined analysis, the cultivar $\times$ environment mean square was significant for both Fusarium head blight incidence and DON concentration, but it was much smaller than the cultivars mean square (Table 3 ). The resistant check cultivar Chevron was least infected by Fusarium head blight and least contaminated with DON (Table 4). Many of the two-row cultivars, particularly AC Alberte and Island, contained a level of Fusarium head blight incidence and DON as low as Chevron.

The three correlation coefficients between DON concentration and Fusarium head blight incidence we studied for sixrow cultivars were all positive and significant at the 0.01 level (Table 5). Only two of the three correlation coefficients for two-row cultivars were significant at the 0.05 level. A negative correlation between DON concentration and plant height was detected for six-row cultivars at Ottawa in both years, indicating that short cultivars were more susceptible to DON accumulation. There was no correlation between DON concentration and plant height at Charlottetown in 2000 and no correlation between Fusarium head blight incidence and plant height at Hangzhou in both years. Correlations between DON concentration and heading date for six-row cultivars were inconsistent, as they varied from year to year and from location to location. DON concentration and barley yellow dwarf were not correlated. None of the correlation coefficients for two-row cultivars were significant except the one between DON concen- tration and Fusarium head blight incidence and the one between DON concentration and heading at Ottawa in 2002.

At Ottawa, the DON concentration of six-row cultivars in 2000 correlated well with that in 2002 (Table 6). Similarly, the DON concentration of six-row cultivars was correlated between the 2 years at Charlottetown. None of the correlation coefficients for DON concentration between Ottawa and Charlottetown were significantly different from zero. Seven of the 20 correlation coefficients for Fusarium head blight incidence and five for heading date were significant. In contrast,

Table 3. Combined analysis of variance for logarithms of $\mathrm{FHB}^{\mathrm{w}}$ incidence $(\%)$ and deoxynivalenol (DON) concentration $\left(\mathrm{mg} \mathrm{kg}^{-1}\right)$ of 17 two-row and 31 six-row barley cultivars grown in Fusarium inoculation tests in six environments

\begin{tabular}{lrcrrr}
\hline & \multicolumn{2}{c}{ FHB incidence $^{\mathbf{x}}$} & & \multicolumn{3}{c}{ DON $^{\mathbf{y}}$} \\
\cline { 2 - 3 } \cline { 5 - 6 } Source & df & Mean square & & df & Mean square \\
\hline Environment (Env) & 4 & $178.5^{* * z}$ & & 3 & $180.7^{* *}$ \\
Error (a) & 11 & 0.6 & & 12 & 2.6 \\
Cultivar & 47 & $3.2^{* *}$ & & 47 & $2.6^{* *}$ \\
Cultivar $\times$ Env & 188 & $0.6^{* *}$ & & 141 & $0.7^{* *}$ \\
Error (b) & 513 & 0.2 & & 562 & 0.2 \\
CV $(\%)$ & & 14.1 & & & 20.1 \\
\hline
\end{tabular}

${ }^{\mathrm{w}}$ Fusarium head blight.

${ }^{x}$ Tested in five environments (Ottawa 2000, Ottawa 2002, Charlottetown 2000, Hangzhou 2000-2001, and Hangzhou 2002-2003).

y Tested in four environments (Ottawa 2000, Ottawa 2002, Charlottetown 2000, and Charlottetown 2002).

$\mathrm{z} * *=$ Significantly different from zero at the 0.01 level.

Table 1. Analysis of variance for logarithms of $\mathrm{FHB}^{\mathrm{v}}$ incidence (\%) of 17 two-row and 31 six-row barley cultivars grown in Fusarium inoculation tests at Ottawa and Charlottetown, Canada, and Hangzhou, China

\begin{tabular}{|c|c|c|c|c|c|c|}
\hline \multirow[b]{2}{*}{ Source } & \multirow[b]{2}{*}{$d f^{w}$} & \multicolumn{5}{|c|}{ Mean square } \\
\hline & & OTTA1 $x$ & OTTA2 & CHAR1 & HANG1 & HANG2 \\
\hline Replicates & 3 & 0.4 & $1.6^{* * \mathrm{y}}$ & 0.0 & $0.29 * *$ & $0.26 * *$ \\
\hline Cultivars & 47 & $2.9^{* *}$ & $3.0 * *$ & $0.3^{* *}$ & $0.24 * *$ & $0.41 * *$ \\
\hline two-row vs. six-row & 1 & $68.1 * *$ & $56.4 * *$ & $1.9^{* *}$ & $4.68^{* *}$ & $15.24 * *$ \\
\hline Within types & 46 & $1.5^{* *}$ & $1.9^{* *}$ & $0.2^{* *}$ & $0.14^{* *}$ & $0.09 * *$ \\
\hline Error & $141^{\mathrm{z}}$ & 0.4 & 0.2 & 0.1 & 0.05 & 0.03 \\
\hline $\mathrm{CV}(\%)$ & & 39.9 & 13.0 & 8.4 & 5.38 & 4.11 \\
\hline
\end{tabular}

${ }^{\mathrm{v}}$ Fusarium head blight.

${ }^{w}$ The df for replicates and error mean squares at Hangzhou was 1 and 47, respectively.

$\times$ OTTA1 = Ottawa 2000, OTTA2 = Ottawa 2002, CHAR1 = Charlottetown 2000, HANG1 = Hangzhou 2000-2001, and HANG2 = Hangzhou $2002-2003$.

$\mathrm{y} * *$ = significantly different from zero at the 0.01 level.

${ }^{\mathrm{z}}$ The df for error mean square at CHAR1 was 137 because of four missing values.

Table 2. Analysis of variance for logarithms of deoxynivalenol (DON) concentration $\left(\mathrm{mg} \mathrm{kg}^{-1}\right)$ of 17 two-row and 31 six-row barley cultivars grown in Fusarium inoculation tests at Ottawa and Charlottetown, Canada, and for the logarithms of DON concentration (mg kg-1) of 16 two-row and 21 six-row barley cultivars grown under natural infection conditions at four locations in Ontario in 2000

\begin{tabular}{|c|c|c|c|c|c|c|c|}
\hline \multirow[b]{3}{*}{ Source } & \multicolumn{5}{|c|}{ Artificial infection } & \multicolumn{2}{|c|}{ Natural infection } \\
\hline & \multirow[b]{2}{*}{ df } & \multicolumn{4}{|c|}{ Mean square } & \multirow[b]{2}{*}{ df } & \multirow{2}{*}{$\begin{array}{c}\text { Mean square } \\
\text { Ontario }\end{array}$} \\
\hline & & OTTA1 $^{w}$ & OTTA2 & CHAR1 & CHAR2 & & \\
\hline Replicates $^{x}$ & 3 & $0.7 * \mathrm{y}$ & $6.1 * *$ & $0.3 * *$ & $2.9 * *$ & 3 & $5.0 * *$ \\
\hline Cultivars & 47 & $2.4 * *$ & $1.3 * *$ & $0.3^{* *}$ & $0.7 * *$ & 36 & $0.4 * *$ \\
\hline 2-row vs. 6-row & 1 & $53.1 * *$ & $13.0 * *$ & 0.0 & $12.2 * *$ & 1 & $10.0 * *$ \\
\hline Within types & 46 & $1.3^{* *}$ & $1.1^{* *}$ & $0.3^{* *}$ & $0.5^{* *}$ & 35 & 0.1 \\
\hline Error & $141^{z}$ & 0.2 & 0.2 & 0.1 & 0.2 & 108 & 0.1 \\
\hline $\mathrm{CV}(\%)$ & & 54.1 & 24.5 & 11.9 & 13.8 & & 39.5 \\
\hline
\end{tabular}

${ }^{\mathrm{w}}$ OTTA1 = Ottawa 2000, OTTA2 = Ottawa 2002, CHAR1 = Charlottetown 2000, and CHAR2 = Charlottetown 2002.

${ }^{\mathrm{x}}$ Locations were treated as replicates in the natural infection test.

$\mathrm{y} *, * *=$ significantly different from zero at the 0.05 and 0.01 level, respectively.

${ }^{z}$ The $\mathrm{df}$ for error mean square at OTTA2 and CHAR1 was 140 because of one missing value. 
almost all of the correlation coefficients for plant height were significant.

Natural infection tests. Among the five locations where the Ontario barley per- formance trial was conducted, Elora had the highest level of DON, followed by Palmerston (Table 7). Ottawa had only traces of DON but severe infection of spot
Table 4. Means of $\mathrm{FHB}^{\mathrm{v}}$ incidence (\%) and deoxynivalenol (DON) concentration ( $\mathrm{mg} \mathrm{kg}^{-1}$ ) of 17 tworow and 31 six-row barley cultivars grown in artificial inoculation tests at Ottawa and Charlottetown, Canada, and Hangzhou, China

\begin{tabular}{|c|c|c|c|c|}
\hline \multirow[b]{2}{*}{ Cultivar } & \multicolumn{2}{|c|}{ FHB incidence ${ }^{w}$} & \multicolumn{2}{|c|}{ DON $^{x}$} \\
\hline & Untransformed & $\begin{array}{c}\text { Log- } \\
\text { transformed }\end{array}$ & Untransformed & $\begin{array}{l}\text { Log- } \\
\text { transformed }\end{array}$ \\
\hline \multicolumn{5}{|c|}{ Two-Row Barley } \\
\hline AC Albertey & 23 & 2.48 & 5 & 1.13 \\
\hline Island & 23 & 2.69 & 7 & 1.37 \\
\hline AB233 & 43 & 3.28 & 8 & 1.40 \\
\hline Sunderland & 32 & 2.93 & 7 & 1.48 \\
\hline Almonte & 31 & 2.87 & 9 & 1.59 \\
\hline Formosa & 36 & 3.17 & 8 & 1.62 \\
\hline AC Parkhill & 28 & 2.69 & 7 & 1.63 \\
\hline AB235-2 & 35 & 3.07 & 10 & 1.72 \\
\hline AC Sirius & 27 & 2.89 & 10 & 1.72 \\
\hline AC Queens & 28 & 2.73 & 12 & 1.75 \\
\hline Belmore & 29 & 2.96 & 9 & 1.78 \\
\hline AC Sterling & 26 & 2.80 & 12 & 1.81 \\
\hline Symko & 29 & 2.75 & 10 & 1.83 \\
\hline Serena & 29 & 2.88 & 9 & 1.88 \\
\hline AC Kings & 31 & 2.99 & 11 & 1.92 \\
\hline Morrison & 36 & 3.27 & 11 & 2.01 \\
\hline AB230 & 32 & 3.12 & 12 & 2.05 \\
\hline Average & $30 \mathrm{a}^{\mathrm{z}}$ & $2.92 \mathrm{a}$ & $9 \mathrm{a}$ & $1.69 \mathrm{a}$ \\
\hline \multicolumn{5}{|l|}{ Six-Row Barley } \\
\hline Chevron & 27 & 2.24 & 7 & 1.02 \\
\hline OAC Kippen & 45 & 3.21 & 11 & 1.67 \\
\hline ACCA & 62 & 3.71 & 15 & 1.88 \\
\hline Myriam & 49 & 3.31 & 11 & 1.98 \\
\hline AC Burman & 61 & 3.93 & 9 & 2.00 \\
\hline OBS4984-6 & 56 & 3.72 & 12 & 2.06 \\
\hline AB186-3 & 54 & 3.69 & 12 & 2.07 \\
\hline Grant & 56 & 3.77 & 11 & 2.08 \\
\hline OBS4755-1 & 45 & 3.62 & 10 & 2.14 \\
\hline AC Hamilton & 60 & 3.87 & 12 & 2.14 \\
\hline Leger & 61 & 3.76 & 13 & 2.15 \\
\hline Excel & 56 & 3.68 & 13 & 2.20 \\
\hline AC Malone & 57 & 3.70 & 13 & 2.20 \\
\hline B1602 & 58 & 3.66 & 13 & 2.20 \\
\hline AC Klinck & 47 & 3.49 & 11 & 2.20 \\
\hline AC Stephen & 62 & 3.88 & 18 & 2.28 \\
\hline AC Vision & 55 & 3.83 & 12 & 2.30 \\
\hline Chapais & 52 & 3.84 & 12 & 2.32 \\
\hline Sandrine & 57 & 3.68 & 17 & 2.34 \\
\hline OBS4985-1 & 56 & 3.88 & 12 & 2.35 \\
\hline AB197-4 & 54 & 3.69 & 15 & 2.36 \\
\hline Viviane & 50 & 3.51 & 17 & 2.37 \\
\hline AC Alma & 59 & 3.86 & 13 & 2.39 \\
\hline Nellygan & 56 & 3.71 & 20 & 2.47 \\
\hline Brucefield & 64 & 4.02 & 15 & 2.52 \\
\hline AC Westech & 51 & 3.61 & 24 & 2.54 \\
\hline AC Maple & 62 & 3.96 & 16 & 2.55 \\
\hline AC Legend & 55 & 3.75 & 17 & 2.56 \\
\hline Stander & 66 & 3.93 & 20 & 2.69 \\
\hline OBS4347-23 & 55 & 3.85 & 22 & 2.72 \\
\hline OBS4840-1 & 69 & 4.11 & 20 & 2.81 \\
\hline Average & $55 \mathrm{~b}$ & $3.69 \mathrm{~b}$ & $14 \mathrm{a}$ & $2.24 \mathrm{a}$ \\
\hline $\operatorname{LSD}(0.05)$ & 15 & 0.56 & 8 & 0.60 \\
\hline
\end{tabular}

${ }^{v}$ Fusarium head blight.

w Tested in five environments (Ottawa 2000, Ottawa 2002, Charlottetown 2000, Hangzhou 2000-2001, and Hangzhou 2002-2003).

x Tested in four environments (Ottawa 2000, Ottawa 2002, Charlottetown 2000, and Charlottetown 2002).

y Hulless barley.

${ }^{\mathrm{z}}$ Average values of each trait followed by different letters were different at the 0.05 level based on the $F$ test. (Note: The average value for DON concentration of the two-row type was not significantly different from that of the six-row type because of [two-row versus six-row] $\times$ environment interactions [see Table 2] and a small degrees of freedom $[\mathrm{df}=3$ ] for the [two-row versus six-row] $\times$ environment mean square which was used as the denominator for the $F$ test.) blotch (data not shown). On the average of four locations, the two-row type contained significantly less DON than the six-row type (Table 2). No significant variation for DON concentration was found among the six-row cultivars and among the two-row cultivars (Table 2). Positive correlation for DON was found only between Westmeath and Elora in six-row cultivars $(r=0.74, P$ $<0.01$ ), but not between any other two locations. Most of the correlation coefficients between DON concentration and other traits in the Ontario barley performance trial were not significantly different from zero (Table 8). Therefore, there appeared to be little relationship of plant height, lodging, heading date, maturity, powdery mildew, and leaf rust with DON accumulation and little relationship of DON concentration with yield, test weight, and seed weight under natural growing conditions in Ontario.

\section{DISCUSSION}

In this study, the six artificial inoculation tests resulted in different levels of Fusarium infection, low incidence at Ottawa but high incidence at both Charlottetown and Hangzhou. Results from the inoculation test at Ottawa resembled those from the 2000 Ontario performance trial in terms of cultivar response and DON level. Overall, the DON concentration at Charlottetown was extremely high, possibly enhanced by a severe natural Fusarium head blight epidemic combined with the added inoculum and misting.

The two-row cultivars in this study differ in their genetic background. Five of them (Formosa, Viking, CM96503, Bogart, and Danuta) were developed in Germany, and the remaining ones were developed in Eastern Canada. Despite this, all two-row cultivars in general were more resistant to Fusarium head blight and DON accumulation than six-row cultivars. In the 2000 Ontario barley performance trial at Elora, Fusarium species were isolated from only 3 of the 18 two-row cultivars; in contrast, they were isolated from 13 of the 28 sixrow cultivars (30). Morphologically speaking, two-row barley is very different from six-row barley. Several factors might lead to better resistance of two-row barley over six-row barley. First, two-row barley provides a less favorable environment for Fusarium species to grow and develop because the heads dry faster $(19,34)$. Second, two-row barley provides less opportunity for Fusarium to spread because its florets do not overlap. Third, the larger concentration of starch in two-row barley may dilute the DON concentration because DON is predominantly concentrated in the hull portion of the grain $(7,11)$ and tworow barley contains $6.5 \%$ more starch than six-row barley (14). These possible reasons are our speculations only, and empirical data are needed to verify if they are valid or not. Many of the correlation coefficients 
for two-row cultivars were not significant in this study. This could be due to a narrow range of DON concentration and Fusarium head blight incidence among the two-row cultivars.

All three correlation coefficients between DON concentration and Fusarium head blight incidence for six-row cultivars were positive, ranging from 0.60 to 0.86 . Therefore, Fusarium head blight incidence can be used for indirect selection for low DON concentration. A positive correlation between DON concentration and Fusarium head blight severity has also been reported by other workers $(8,16,32,34)$. But Tekauz et al. (31) found that DON concentration was not correlated with Fusarium head blight index in a cultivar evaluation trial in Manitoba. Plant height was negatively correlated with DON concentration at Ottawa, but it was not correlated with DON concentration at Charlottetown and with Fusarium head blight incidence at Hangzhou. This could be due to the inoculation methods used at these three locations. In Ottawa, infected kernels were broadcast onto the plots, and thus heads of tall cultivars were farther away from the source of inoculum on the ground and had less favorable micro-environmental conditions than those of short cultivars (34). In contrast, plant height played no role in the Fusarium head blight infection at Charlottetown and Hangzhou, possibly because inoculum was applied at least once from the top spraying. In this study, heading date was correlated with DON concentration at Ottawa and with Fusarium head blight incidence at Hangzhou. This finding could be attributed to the fact that earlyheading cultivars were subjected to more disease pressure than late-heading cultivars because inoculum was applied at these two locations from before heading to the heading stage. In contrast, inoculum was applied from the heading stage to 2 weeks after heading at Charlottetown, and thus late-heading cultivars (including most of the two-row) were subjected to more disease pressure than early-heading cultivars. Barley yellow dwarf and powdery mildew appeared to have very little effect on Fusarium head blight infection in this study. Previously, Perkowski et al. (22) and Chełkowski et al. (4) reported that artificially inoculated heads produced fewer seeds, lower seed weight, and lower seed yield per head in barley. In the epidemic year of 2000 in Ontario, susceptibility to DON accumulation seemed to have very little effect on seed weight, test weight, and grain yield. In fact, the vast majority of the correlation coefficients under natural infection conditions were not significant.

The DON concentration at Ottawa was not correlated with that at Charlottetown. The Fusarium head blight incidence at Ottawa, however, was correlated with the Fusarium head blight incidence at Charlottetown in three of the four cases we studied (Table 6). Although no Fusarium head blight severity data were collected at these two locations, we did observe that only one or two kernels per head were infected by Fusarium head blight at Ottawa, but heads were severely infected at Charlottetown. Therefore, cultivar differences in resistance to the spread of the

Table 5. Correlation coefficients of 17 two-row and 31 six-row barley cultivars grown in Fusarium inoculation tests at Ottawa and Charlottetown, Canada, and Hangzhou, China

\begin{tabular}{lccc}
\hline Traits & Range $^{\mathbf{w}}$ & Two-row cultivars & Six-row cultivars \\
\hline Ottawa 2000 & & & \\
DON \& FHB & & \\
DON \& height (cm) & $1-22$ & 0.32 & $0.86^{* * y}$ \\
DON \& heading (day) & $79-113$ & -0.39 & $-0.57^{* *}$ \\
DON \& BYD (0-9) & $44-57$ & -0.26 & $-0.59^{* *}$ \\
Ottawa 2002 & $0.0-4.8$ & 0.01 & \\
DON \& FHB incidence (\%) & $1-60$ & & $0.61^{* * *}$ \\
DON \& height (cm) & $64-106$ & -0.04 & $-0.61^{* *}$ \\
DON \& heading (days) & $54-69$ & $-0.49^{*}$ & 0.28 \\
Charlottetown 2000 & & & \\
DON \& FHB incidence (\%) & $20-74$ & 0.37 & $0.60^{* *}$ \\
DON \& height (cm) & $76-106$ & 0.42 & 0.29 \\
Charlottetown 2002 & & & \\
DON \& heading (days) & $52-62$ & 0.04 & $0.55^{* *}$ \\
Hangzhou 2000-2001 & & & \\
FHB incidence \& height (cm) & $76-114$ & -0.14 & 0.00 \\
FHB incidence \& heading (days) & $141-156$ & -0.30 & $-0.50^{* *}$ \\
Hangzhou 2002-2003 & & & -0.06 \\
FHB incidence \& height (cm) & $71-117$ & -0.39 & -0.32 \\
FHB incidence \& heading (days) & $152-163$ & -0.33 & \\
\hline
\end{tabular}

${ }^{\mathrm{w}}$ Maximum and minimum values of the second trait.

${ }^{\mathrm{x}}$ Fusarium head blight.

$\mathrm{y} *, * *=$ significantly different at the 0.05 and 0.01 level, respectively.

${ }^{\mathrm{z}}$ Barley yellow dwarf $(0=$ no leaf chlorosis, $9=$ sever leaf chlorosis $)$.

Table 6. Correlation coefficients of 17 two-row and 31 six-row barley cultivars grown in Fusarium inoculation tests at Ottawa and Charlottetown, Canada, and Hangzhou, China

\begin{tabular}{lcccc}
\hline Tests & DON & FHB incidence & Heading & Height \\
\hline Two-Row Barley & & & & \\
OTTA1 \& OTTA2 & -0.12 & 0.06 & $0.51^{* *}$ & $0.56^{*}$ \\
OTTA1 \& CHAR1 & 0.09 & 0.30 & $\ldots$ & $0.68^{* *}$ \\
OTTA1 \& CHAR2 & 0.32 & $\ldots$ & $0.67^{* *}$ & $\ldots$ \\
OTTA1 \& HANG1 & $\ldots$ & 0.46 & 0.29 & 0.36 \\
OTTA1 \& HANG2 & $\ldots$ & -0.31 & -0.24 & $0.56^{*}$ \\
OTTA2 \& CHAR1 & 0.28 & $0.58^{*}$ & $\ldots$ & $0.74^{* *}$ \\
OTTA2 \& CHAR2 & $\ldots$ & $\ldots$ & 0.41 & $\ldots$ \\
OTTA2 \& HANG1 & $\ldots$ & 0.08 & 0.05 & 0.46 \\
OTTA2 \& HANG2 & $\ldots$ & 0.20 & -0.45 & $0.55^{*}$ \\
CHAR1 \& CHAR2 & 0.39 & $\ldots$ & $\ldots$ & $\ldots$ \\
CHAR1 \& HANG1 & $\ldots$ & -0.02 & $\ldots$ & $0.61^{* *}$ \\
CHAR1 \& HANG2 & $\ldots$ & -0.18 & $\ldots$ & $0.71^{* *}$ \\
CHAR2 \& HANG1 & $\ldots$ & $\ldots$ & 0.27 & $\ldots$ \\
CHAR2 \& HANG2 & $\ldots$ & $\ldots$ & -0.19 & $\ldots$ \\
HANG1 \& HANG2 & $\ldots$ & 0.31 & -0.13 & -0.21 \\
Six-Row Barley & & & & \\
OTTA1 \& OTTA2 & $0.71 * *$ & $0.60^{* *}$ & 0.29 & $0.71^{* *}$ \\
OTTA1 \& CHAR1 & 0.16 & $0.52^{* *}$ & $\ldots$ & $0.72^{* *}$ \\
OTTA1 \& CHAR2 & 0.13 & $\ldots$ & $0.61 * *$ & $\ldots$ \\
OTTA1 \& HANG1 & $\ldots$ & 0.08 & -0.05 & $0.71^{* *}$ \\
OTTA1 \& HANG2 & $\ldots$ & $0.39^{*}$ & -0.20 & $0.78^{* *}$ \\
OTTA2 \& CHAR1 & 0.34 & $0.77^{* *}$ & $\ldots$ & $0.55^{* *}$ \\
OTTA2 \& CHAR2 & 0.35 & $\ldots$ & 0.24 & $\ldots$ \\
OTTA2 \& HANG1 & $\ldots$ & 0.04 & $0.48^{* *}$ & $0.58^{* * *}$ \\
OTTA2 \& HANG2 & $\ldots$ & $0.81^{* *}$ & $0.44^{*}$ & $0.53^{* *}$ \\
CHAR1 \& CHAR2 & $0.50^{* *}$ & $\ldots$ & $\ldots$ & $\ldots$ \\
CHAR1 \& HANG1 & $\ldots$ & $\ldots .03$ & $\ldots$ & $0.48^{* *}$ \\
CHAR1 \& HANG2 & $\ldots$ & $0.66^{* *}$ & $\ldots$ & $\ldots .61^{* *}$ \\
CHAR2 \& HANG1 & $\ldots$ & $\ldots$ & 0.06 & $\ldots$ \\
CHAR2 \& HANG2 & $\ldots$ & $\ldots$ & -0.14 & $\ldots .70^{* *}$ \\
HANG1 \& HANG2 & $\ldots$ & 0.34 & 0.21 & \\
\hline & & & &
\end{tabular}

${ }^{\mathrm{x}}$ Fusarium head blight.

${ }^{\mathrm{y}}$ OTTA 1 = Ottawa 2000, OTTA2 = Ottawa 2002, CHAR1 $=$ Charlottetown 2000, CHAR2 = Charlottetown 2002, HANG1 = Hangzhou 2000-2001, and HANG2 = Hangzhou 2002-2003.

$\mathrm{z} *, * *=$ significantly different from zero at the 0.05 and 0.01 level, respectively. 
Table 7. Deoxynivalenol (DON) concentration $\left(\mathrm{mg} \mathrm{kg}^{-1}\right)$ of 18 two-row and 25 six-row barley cultivars grown at five locations across Ontario in $2000^{\mathrm{v}}$

\begin{tabular}{|c|c|c|c|c|c|c|}
\hline \multirow[b]{2}{*}{ Cultivar } & \multirow[b]{2}{*}{ Westmeath } & \multirow[b]{2}{*}{ Elora } & \multirow[b]{2}{*}{ Palmerston } & \multirow[b]{2}{*}{ Winthrop } & \multicolumn{2}{|c|}{ Meanw $^{w}$} \\
\hline & & & & & Untransformed & Log-transformed \\
\hline \multicolumn{7}{|l|}{ Two-Row Barley } \\
\hline AC Alberte ${ }^{x}$ & 0.0 & 0.5 & 0.5 & 0.1 & 0.27 & 0.23 \\
\hline Britton & 0.0 & 0.7 & 0.3 & 0.4 & 0.35 & 0.28 \\
\hline AC Kings & 0.0 & 0.7 & 0.3 & 0.4 & 0.35 & 0.28 \\
\hline Benefit & 0.0 & 1.0 & 0.3 & 0.2 & 0.37 & 0.28 \\
\hline AC Parkhill & 0.0 & 1.0 & 0.2 & 0.3 & 0.37 & 0.28 \\
\hline Sunderland & 0.0 & 1.0 & 0.3 & 0.2 & 0.37 & 0.28 \\
\hline Belmore & 0.4 & 0.7 & 0.2 & 0.3 & 0.40 & 0.32 \\
\hline Bradford & 0.2 & 0.5 & 0.5 & 0.6 & 0.45 & 0.37 \\
\hline AC Sterling & 0.1 & 0.5 & 0.6 & 0.8 & 0.50 & 0.39 \\
\hline Bogart & 0.1 & 1.5 & 0.3 & 0.2 & 0.52 & 0.36 \\
\hline Bristol & 0.2 & 1.1 & 1.3 & 0.5 & 0.77 & 0.54 \\
\hline Morrison & 0.0 & 1.0 & 1.0 & 1.2 & 0.80 & 0.54 \\
\hline Almonte & 0.0 & 0.3 & 0.4 & 2.6 & 0.82 & 0.47 \\
\hline AC Sirius & 0.0 & 2.2 & 0.7 & 1.0 & 0.97 & 0.60 \\
\hline Danuta & 0.0 & 2.1 & 0.9 & 1.4 & 1.10 & 0.66 \\
\hline CM96503 & 0.4 & 3.5 & 0.4 & 0.5 & 1.20 & 0.65 \\
\hline Formosa & $\ldots{ }^{\mathrm{y}}$ & 1.6 & 0.4 & 0.2 & $\ldots$ & $\ldots$ \\
\hline Viking & $\ldots$ & 0.9 & 0.3 & 1.0 & $\ldots$ & $\ldots$ \\
\hline Average & $0.1 \mathrm{a}^{\mathrm{z}}$ & $1.2 \mathrm{a}$ & $0.5 \mathrm{a}$ & $0.7 \mathrm{a}$ & $0.60 \mathrm{a}$ & $0.41 \mathrm{a}$ \\
\hline \multicolumn{7}{|l|}{ Six-Row Barley } \\
\hline CM862.6 & 0.0 & 1.5 & 1.6 & 0.9 & 1.00 & 0.63 \\
\hline Banner & 0.0 & 2.1 & 1.6 & 0.8 & 1.12 & 0.67 \\
\hline Badger & 0.0 & 2.2 & 1.7 & 0.6 & 1.12 & 0.66 \\
\hline ACCA & 0.3 & 1.5 & 2.3 & 1.3 & 1.35 & 0.80 \\
\hline OAC Kippen & 0.5 & 3.6 & 1.3 & 0.2 & 1.40 & 0.74 \\
\hline AC Alma & 0.6 & 2.1 & 3.0 & 0.8 & 1.62 & 0.89 \\
\hline Chapais & 0.6 & 3.7 & 2.0 & 0.2 & 1.62 & 0.82 \\
\hline AC Hamilton & 0.4 & 2.9 & 2.5 & 0.7 & 1.62 & 0.87 \\
\hline OAC Baxter & 1.4 & 3.6 & 1.3 & 0.6 & 1.72 & 0.93 \\
\hline AB186-3 & 0.8 & 4.3 & 1.4 & 0.5 & 1.74 & 0.88 \\
\hline AC Klinck & 0.7 & 4.1 & 1.8 & 0.6 & 1.80 & 0.91 \\
\hline AC Legend & 1.0 & 3.1 & 2.4 & 1.1 & 1.90 & 1.02 \\
\hline AC Vision & 1.0 & 3.9 & 2.2 & 0.8 & 1.97 & 1.01 \\
\hline AC Maple & 0.5 & 4.4 & 2.6 & 0.5 & 2.00 & 0.94 \\
\hline Viviane & 0.5 & 3.3 & 3.0 & 1.8 & 2.15 & 1.07 \\
\hline OBS4065-157 & 0.5 & 4.8 & 1.8 & 1.6 & 2.17 & 1.04 \\
\hline AC Westech & 0.8 & 5.5 & 2.0 & 0.7 & 2.25 & 1.02 \\
\hline Balance & 1.1 & 3.6 & 4.0 & 0.7 & 2.35 & 1.10 \\
\hline AC Stephen & 1.3 & 4.6 & 2.5 & 1.0 & 2.35 & 1.13 \\
\hline Grant & 0.7 & 6.4 & 1.9 & 0.8 & 2.45 & 1.05 \\
\hline Brucefield & 2.6 & 8.2 & 2.9 & 1.4 & 3.77 & 1.43 \\
\hline Blakeney & 1.0 & $\ldots$ & $\ldots$ & $\ldots$ & $\ldots$ & $\ldots$ \\
\hline Foster & 0.5 & $\ldots$ & $\ldots$ & $\ldots$ & $\ldots$ & $\ldots$ \\
\hline Myriam & 1.2 & $\ldots$ & $\ldots$ & $\ldots$ & $\ldots$ & $\ldots$ \\
\hline Sandrine & 1.2 & $\ldots$ & $\ldots$ & $\ldots$ & $\ldots$ & $\ldots$ \\
\hline Nellygan & $\cdots$ & 4.8 & 1.7 & 2.3 & $\ldots$ & $\ldots$ \\
\hline Average & $0.8 \mathrm{~b}$ & $3.8 \mathrm{~b}$ & $2.2 \mathrm{~b}$ & $0.9 \mathrm{a}$ & $1.88 \mathrm{~b}$ & $0.93 \mathrm{~b}$ \\
\hline $\operatorname{LSD}(0.05)$ & $\ldots$ & $\ldots$ & $\ldots$ & $\ldots$ & 1.26 & 0.39 \\
\hline
\end{tabular}

${ }^{\mathrm{v}}$ All barley cultivars grown at Ottawa did not contain DON except Viviane and CM862.6, which contained $0.1 \mathrm{mg} \mathrm{kg}^{-1}$.

${ }^{w}$ Means of four locations (Westmeath, Elora, Palmerston, and Winthrop).

${ }^{x}$ Hulless barley.

y Not determined.

${ }^{\mathrm{z}}$ Average values followed by the same letter were not significantly different at the 0.05 level based on the $F$ test.

infection within a plant at Charlottetown could account for the lack of DON correlation between the two locations. Fusarium head blight incidence of six-row cultivars at Hangzhou in 2002-2003 was correlated with that at Ottawa in 2002 and also with that at Charlottetown in 2000 (Table 6). Therefore, responses of six-row cultivars to Fusarium head blight in Canada sometimes were similar to those in Hangzhou. Three cultivars (AC Alberte, Island, and Chevron) were consistently low in DON across all three locations despite the fact that Fusarium isolates, inoculation methods, and growing conditions were all dif- ferent among the three locations. Therefore, it appears that China can be useful for providing additional environments for screening for Fusarium head blight resistance.

Recently, Tekauz et al. (31) found that AC Sterling contained a low level of DON in an inoculation test. In our study, AC Sterling had a low Fusarium head blight incidence at Hangzhou; it also contained a low level of DON at the Ottawa inoculation test and the Ontario barley performance trial. But it contained a relatively high level of DON at the Charlottetown test. Island (6) seemed to be most resistant to
Fusarium head blight. Island had the lowest Fusarium head blight incidence, even lower than Chevron, at Hangzhou. Island was also among the lowest in DON concentration at both Charlottetown and Ottawa. The hulless barley AC Alberte (5) did well in all of the tests, probably because of both hullessness and Fusarium head blight resistance. As pointed out by Clear et al. (7), dehulling of hulless barley during harvest can reduce the DON concentration by $59 \%$. Similarly, Island (1.7 and $0.5 \mathrm{mg}$ $\mathrm{kg}^{-1}$ ) and AC Alberte (1.8 and $0.2 \mathrm{mg} \mathrm{kg}{ }^{-1}$ ) were found to contain DON levels as low as Chevron (1.4 and $\left.0.5 \mathrm{mg} \mathrm{kg}^{-1}\right)$ in artifi- 
Table 8. Correlation coefficients of barley cultivars grown at four locations (Westmeath, Elora, Palmerston, and Winthrop) in Ontario in 2000

\begin{tabular}{|c|c|c|c|}
\hline Traits & Range $^{u}$ & Two-row cultivars & Six-row cultivars \\
\hline \multicolumn{4}{|l|}{ Westmeath } \\
\hline DON \& yield $\left(\mathrm{t} \mathrm{ha}^{-1}\right)$ & $1.44-3.87$ & -0.20 & 0.12 \\
\hline DON \& test weight $\left(\mathrm{kg} \mathrm{hl}^{-1}\right)$ & $58-74$ & 0.02 & -0.14 \\
\hline DON \& seed weight $(\mathrm{mg})$ & $31-42$ & 0.08 & $0.51 * * \mathrm{v}$ \\
\hline DON \& height $(\mathrm{cm})$ & $66-101$ & -0.32 & 0.05 \\
\hline DON \& heading (days) & $45-52$ & -0.08 & -0.26 \\
\hline DON \& maturity (days) & $77-84$ & -0.08 & -0.23 \\
\hline \multicolumn{4}{|l|}{ Elora } \\
\hline DON \& yield $\left(\mathrm{t} \mathrm{ha}^{-1}\right)$ & $3.20-5.20$ & 0.35 & 0.21 \\
\hline DON \& test weight $\left(\mathrm{kg} \mathrm{hl}^{-1}\right)$ & $46-68$ & $-0.63 * *$ & -0.13 \\
\hline DON \& seed weight $(\mathrm{mg})$ & $23-47$ & 0.01 & 0.13 \\
\hline DON \& height $(\mathrm{cm})$ & $73-100$ & $-0.58 *$ & -0.14 \\
\hline DON \& lodging $(0-9)^{\mathrm{w}}$ & $1.5-7.0$ & -0.12 & 0.13 \\
\hline DON \& maturity (days) & $99-105$ & $-0.54 *$ & -0.17 \\
\hline DON \& powdery mildew $(0-9)^{x}$ & $0.0-8.0$ & $-0.55^{*}$ & -0.04 \\
\hline DON \& leaf rust $(0-9)^{\mathrm{x}}$ & $0.0-8.0$ & $-0.50 *$ & -0.08 \\
\hline \multicolumn{4}{|l|}{ Palmerston } \\
\hline DON \& yield $\left(\mathrm{t} \mathrm{ha}^{-1}\right)$ & $2.81-4.94$ & 0.04 & 0.33 \\
\hline DON \& test weight $\left(\mathrm{kg} \mathrm{hl}^{-1}\right)$ & $45-61$ & -0.08 & 0.11 \\
\hline DON \& seed weight (mg) & $25-43$ & 0.05 & -0.05 \\
\hline DON \& height $(\mathrm{cm})$ & $73-102$ & 0.05 & -0.03 \\
\hline DON \& lodging $(0-9)^{\mathrm{w}}$ & $1.3-8.3$ & 0.08 & -0.36 \\
\hline DON \& powdery mildew $(0-9)^{\mathrm{x}}$ & $0.0-8.5$ & 0.30 & 0.19 \\
\hline DON \& leaf rust $(0-9)^{\mathrm{x}}$ & $0.0-3.5$ & -0.10 & 0.07 \\
\hline \multicolumn{4}{|l|}{ Winthrop } \\
\hline DON \& yield $\left(\mathrm{t} \mathrm{ha}^{-1}\right)$ & $2.49-5.20$ & 0.44 & 0.06 \\
\hline DON \& test weight $\left(\mathrm{kg} \mathrm{hl}^{-1}\right)$ & $60-77$ & -0.35 & -0.19 \\
\hline DON \& seed weight (mg) & $37-50$ & -0.25 & -0.07 \\
\hline DON \& height $(\mathrm{cm})$ & $76-105$ & 0.07 & 0.19 \\
\hline DON \& heading (days) & $56-61$ & $0.56^{*}$ & $0.50 *$ \\
\hline DON \& stem break $(0-9)^{\mathrm{y}}$ & $1.0-8.0$ & 0.16 & 0.21 \\
\hline DON \& neck break $(0-9)^{y}$ & $0.0-8.0$ & -0.08 & 0.28 \\
\hline DON \& powdery mildew $(0-9)^{\mathrm{x}}$ & $0.0-6.5$ & 0.17 & 0.15 \\
\hline DON \& net blotch $(0-9)^{x}$ & $4.0-6.5$ & -0.15 & -0.11 \\
\hline DON \& leaf rust $(0-9)^{\mathrm{x}}$ & $0.0-4.5$ & 0.27 & -0.14 \\
\hline DON \& stem rust $(0-9)^{x}$ & $1.0-4.0$ & -0.44 & 0.18 \\
\hline DON \& brightness $(0-9)^{\mathrm{z}}$ & $3.0-6.5$ & 0.16 & -0.24 \\
\hline
\end{tabular}

u Maximum and minimum values of the second trait.

$\mathrm{v} *, * *=$ significant at the 0.05 and 0.01 level, respectively.

${ }^{\mathrm{w}} 0=$ no lodging, $9=$ severe lodging.

× $0=$ no disease, $9=$ severe disease.

у $0=$ no breakage, $9=$ severe breakage.

${ }^{\mathrm{z}} 0=$ severe discoloration, $9=$ brightest color.

cial inoculation tests with six and three replications at St. Hyacinthe (Quebec) in 2000 and 2001, respectively (S. Rioux, unpublished data).

In conclusion, none of the barley cultivars were immune to Fusarium head blight infection. Two-row cultivars, however, were more resistant to Fusarium head blight infection and DON accumulation than six-row cultivars. In six-row barley, DON concentration was correlated positively with Fusarium head blight incidence at both Charlottetown and Ottawa, and it was negatively correlated with plant height at Ottawa. DON concentration and heading date were not consistently correlated. Island, AC Alberte, and Chevron were found to be most resistant, as they were consistently low in Fusarium head blight incidence and DON concentration in both Canada and China.

\section{ACKNOWLEDGMENTS}

The technical assistance of Dan Murphy, Mike Burville, Flo Sabo, Sally Buffam, Ron Matters, Wayne Hogan, and Jianming Yang is gratefully acknowledged. The authors thank Robert W. Stack,
Ruth Dill-Mackey, Timothy Paulitz, and Jeannie Gilbert for their advice on the inoculation method, Sylvie Rioux (Centre de recherche sur les grains) for her unpublished data, and barley breeders in Eastern Canada for providing seeds of their cultivars for this study.

\section{LITERATURE CITED}

1. Bottalico, A. 1998. Fusarium diseases of cereals: Species complex and related mycotoxin profiles, in Europe. J. Plant Pathol. 80:85-103.

2. Campbell, H., Choo, T. M., Vigier, B., and Underhill, L. 2000. Mycotoxins in barley and oat samples from Eastern Canada. Can. J. Plant Sci. 80:977-980.

3. Campbell, H., Choo, T. M., Vigier, B., and Underhill, L. 2002. Comparison of mycotoxin profiles among cereal samples from Eastern Canada. Can. J. Bot. 80:526-532.

4. Chełkowski, J., Wiśniewska, H., Adamski, T., Goliński, P., Kaczmarek, Z., Kostecki, M., Perkowski, J, and Surma, M. 2000. Effects of Fusarium culmorum head blight on mycotoxin accumulation and yield traits in barley doubled haploids. J. Phytopathol. 148:541-545.

5. Choo, T. M., Martin, R. A., ter Beek, S., Ho, K. M., Caldwell, C. D., Walker, D., and Rodd, V. 2001. AC Alberte hulless barley. Can. J. Plant Sci. 81:425-426.

6. Choo, T. M., Martin, R. A., ter Beek, S. M.,
Ho, K. M., Caldwell, C. D., Walker, D., Rodd, V., Dion, Y., and Rioux, S. 2003. Island barley. Can. J. Plant Sci. 83:793-795.

7. Clear, R. M., Patrick, S. K., Nowicki, T., Gaba D., Edney, M., and Babb, J. C. 1997. The effect of hull removal and pearling on Fusarium species and trichothecenes in hulless barley. Can. J. Plant Sci. 77:161-166.

8. de la Pena, R. C., Smith, K. P., Capettini, F., Muehlbauer, G. J., Gallo-Meagher, M., DillMacky, R., Somers, D. A., and Rasmusson, D. C. 1999. Quantitative trait loci associated with resistance to Fusarium head blight and kernel discoloration in barley. Theor. Appl. Genet. 99:561-569.

9. Greig, J. 2000. Barley bashed by fusarium for the first time. Ontario Farmer 33(27):2B.

10. Guitard, A. A. 1960. The use of diallel correlations for determining the relative locational performance of varieties of barley. Can. J. Plant Sci. 40:645-651.

11. House, J. D., Nyachoti, C. M., and Abramson, D. 2003. Deoxynivalenol removal from barley intended as swine feed through the use of an abrasive pearling procedure. J. Agric. Food Chem. 51:5172-5175.

12. Kim, J. C., Kang, H. J., Lee, D. H., Lee, Y. W., and Yoshizawa, T. 1993. Natural occurrence of Fusarium mycotoxins (Trichothecenes and zearalenone) in barley and corn in Korea. Appl. Environ. Microbiol. 59:3798-3802.

13. Koizumi, S., Kato, H., Yoshino, R., Hayashi, N., and Ichinoe, M. 1991. Distribution of causal fusaria of wheat and barley scab in Japan. Ann. Phytopathol. Soc. Jpn. 57:165-173.

14. Kong, D., Choo, T. M., Jui, P., Ferguson, T., Therrien, M. C., Ho, K. M., May, K. W., and Narasimhalu, P. 1995. Variation in starch, protein, and fibre of Canadian barley cultivars Can. J. Plant Sci. 75:865-870.

15. Lu, L., ed. 1996. Barley science in China. (In Chinese.) China Agriculture Press, Beijing, China.

16. Ma, Z., Steffenson, B. J., Prom, L. K., and Lapitan, N. L. V. 2000. Mapping of quantitative trait loci for Fusarium head blight resistance in barley. Phytopathology 90:1079-1088.

17. Martin, R. A., and Johnston, H. W. 1982 Effects and control of fusarium diseases of cereal grains in the Atlantic Provinces. Can. J Plant Pathol. 4:210-216.

18. McMullen, M., Jones, R., and Gallenberg, D. 1997. Scab of wheat and barley: A re-emerging disease of devastating impact. Plant Dis. 81:1340-1348.

19. Mesfin, A., Smith, K. P., Dill-Macky, R. Evans, C. K., Waugh, R., Gustus, C. D., and Muehlbauer, G. J. 2003. Quantitative traits loci for Fusarium head blight resistance in barley detected in a two-rowed by six-rowed population. Crop Sci. 43:307-318.

20. Mesterházy, Á., and Rowaished, A. K. 1977. Analysis of symptoms caused by Fusarium graminearum Schwabe and its relation to powdery mildew infection in wheat. Acta Phytopathol. Acad. Sci. Hung.12:289-301.

21. Neish, G. A., and Cohen, H. 1981. Vomitoxin and zearalenone production by Fusarium graminerum from winter wheat and barley in Ontario. Can. J. Plant Sci. 61:811-815.

22. Perkowski, J., Kiecana, I., and Chełkowski, J. 1995. Susceptibility of barley cultivars and lines to Fusarium infection and mycotoxin accumulation in kernels. J. Phytopathol. 143:547-551.

23. Salas, B., Steffenson, B. J., Casper, H. H., Tacke, B., Prom, L. K., Fetch, T. G., Jr., and Schwarz, P. B. 1999. Fusarium species pathogenic to barley and their associated mycotoxins. Plant Dis. 83:667-674.

24. Shands, R. G. 1939. Chevron, a barley variety resistant to stem rust and other diseases. Phytopathlogy 29:209-211.

25. Sinha, R. C., and Savard, M. E. 1996. Com- 
parison of immunoassay and gas chromatography methods for the detection of the mycotoxin deoxynivalenol in grain samples. Can. J. Plant Pathol. 18:233-236.

26. Sinha, R. C., Savard, M. E., and Lau, R. 1995. Production of monoclonal antibodies for the specific detection of deoxynivalenol and 15acetyldeoxynivalenol by ELISA. J. Agric. Food Chem. 43:1740-1744.

27. Steffenson, B. J. 1998. Fusarium head blight of barley: Epidemics, impact, and breeding for resistance. MBAA Tech. Quart. 35:177-184.

28. Takeda, K. 1990. Selection response and parentoffspring correlation of the resistance to Fusarium head blight in barley. (In Japanese, with English abstract.) Jpn. J. Breed. 40:91-101.
29. Takeda, K., and Heta, H. 1989. Establishing the testing method and a search for the resistant varieties to Fusarium head blight in barley. (In Japanese, with English abstract.) Jpn. J. Breed. 39:203-216.

30. Tamburic-Ilincic, L., Falk, D. E., and Schaafsma, A. W. 2000. Fusarium head blight in barley in Ontario in 2000. Pages 187-191 in: Proc. 2000 National Fusarium Head Blight Forum, Erlanger, KY

31. Tekauz, A., McCallum, B., and Gilbert, J. 2000. Review: Fusarium head blight of barley in western Canada. Can. J. Plant Pathol. 22:916.

32. Urrea, C. A., Horsley, R. D., Steffenson, B. J., and Schwarz, P. B. 2002. Heritability of Fusa- rium head blight resistance and deoxynivalenol accumulation from barley accession Ciho 4196. Crop Sci. 42:1404-1408.

33. Zhou, X., Chao, M., and Liang, X. 1991. Screening and testing of barley varieties for scab resistance. (In Chinese, with English ab stract.) Acta Phytophylacica Sin. 18:261-265.

34. Zhu, H., Gilchrist, L., Hayes, P., Kleinhofs, A., Kudrna, D., Liu, Z., Prom, L., Steffenson, B., Toojinda, T., and Vivar, H. 1999. Does function follow form? Principal QTLs for Fusarium head blight (FHB) resistance are coincident with QTLs for inflorescence traits and plant height in a doubled-haploid population of barley. Theor. Appl. Genet. 99:12211232 . 